for conservation globally

Threatened

通
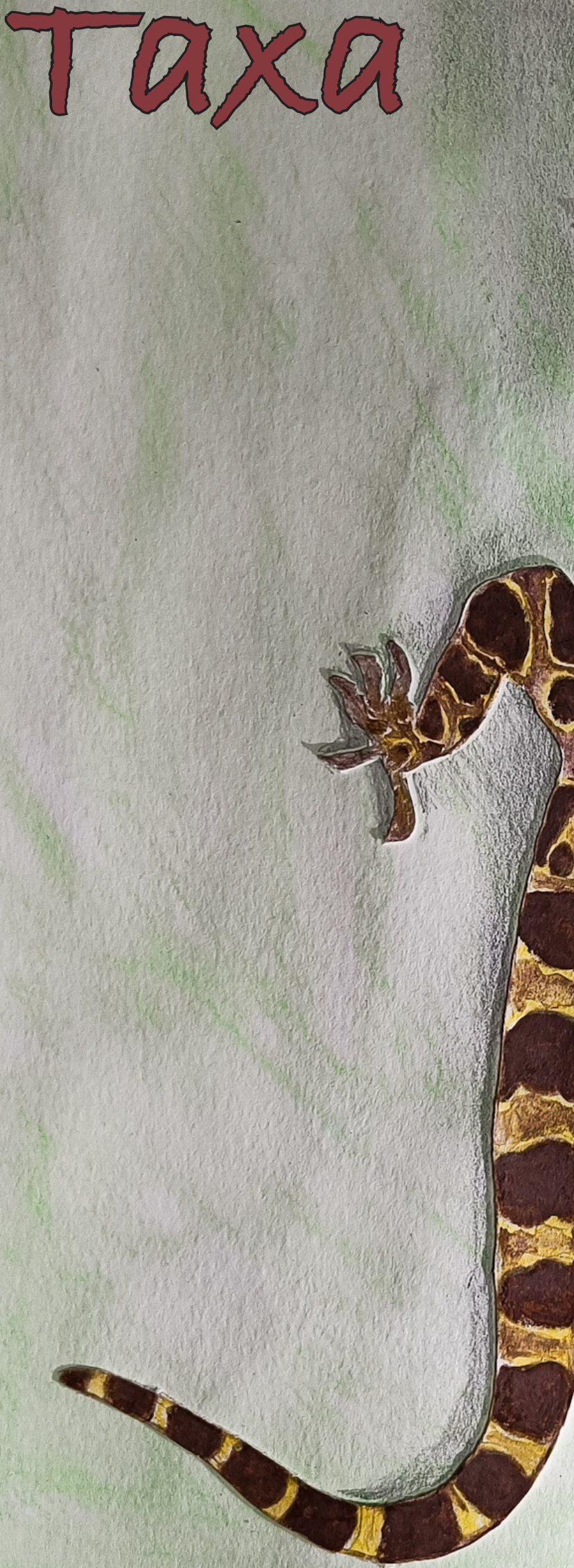

Open Access

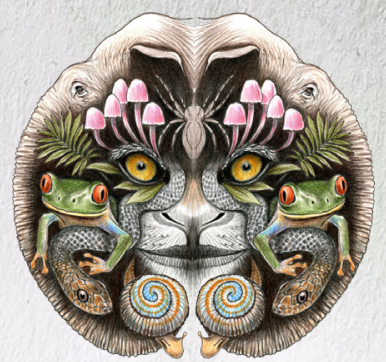

$10.1160 \mathrm{~g} / \mathrm{j}$ ott.2022.14.1.20311-20538 wWw.threatenedtaxa.org

26 January 2022 (Online \& Print) 14(1): 20311-20538 ISSN0974-7907 (Online) ISSN 0974-7893 (Print) 


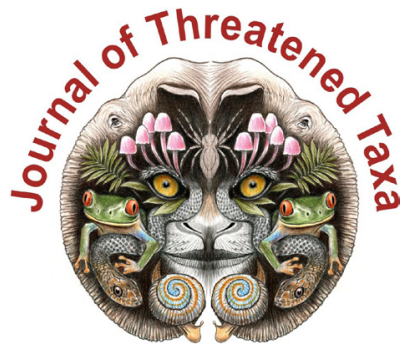

ISSN 0974-7907 (Online); ISSN $0974-7893$ (Print)

Publisher

Host

Wildlife Information Liaison Development Society

www.wild.zooreach.org

Zoo Outreach Organization www.zooreach.org

No. 12, Thiruvannamalai Nagar, Saravanampatti - Kalapatti Road, Saravanampatti, Coimbatore, Tamil Nadu 641035, India

Ph: +91 9385339863 | www.threatenedtaxa.org

Email: sanjay@threatenedtaxa.org

EDITORS

\section{Founder \& Chief Editor}

Dr. Sanjay Molur

Wildlife Information Liaison Development (WILD) Society \& Zoo Outreach Organization (ZOO),

12 Thiruvannamalai Nagar, Saravanampatti, Coimbatore, Tamil Nadu 641035, India

\section{Deputy Chief Editor}

Dr. Neelesh Dahanukar

Noida, Uttar Pradesh, India

\section{Managing Editor}

Mr. B. Ravichandran, WILD/ZOO, Coimbatore, India

\section{Associate Editors}

Dr. Mandar Paingankar, Government Science College Gadchiroli, Maharashtra 442605, India

Dr. Ulrike Streicher, Wildlife Veterinarian, Eugene, Oregon, USA

Ms. Priyanka Iyer, ZOO/WILD, Coimbatore, Tamil Nadu 641035, India

Dr. B.A. Daniel, ZOO/WILD, Coimbatore, Tamil Nadu 641035, India

\section{Editorial Board}

Dr. Russel Mittermeier

Executive Vice Chair, Conservation International, Arlington, Virginia 22202, USA

\section{Prof. Mewa Singh Ph.D., FASc, FNA, FNASc, FNAPsy}

Ramanna Fellow and Life-Long Distinguished Professor, Biopsychology Laboratory, and Institute of Excellence, University of Mysore, Mysuru, Karnataka 570006, India; Honorary Professor, Jawaharlal Nehru Centre for Advanced Scientific Research, Bangalore; and Adjunct Professor, National Institute of Advanced Studies, Bangalore

\section{Stephen D. Nash}

Scientific Illustrator, Conservation International, Dept. of Anatomical Sciences, Health Sciences Center, T-8, Room 045, Stony Brook University, Stony Brook, NY 11794-8081, USA

\section{Dr. Fred Pluthero}

Toronto, Canada

\section{Dr. Priya Davidar}

Sigur Nature Trust, Chadapatti, Mavinhalla PO, Nilgiris, Tamil Nadu 643223, India

\section{Dr. Martin Fisher}

Senior Associate Professor, Battcock Centre for Experimental Astrophysics, Cavendish

Laboratory, JJ Thomson Avenue, Cambridge CB3 OHE, UK

\section{Dr. John Fellowes}

Honorary Assistant Professor, The Kadoorie Institute, 8/F, T.T. Tsui Building, The University of Hong Kong, Pokfulam Road, Hong Kong

\section{Prof. Dr. Mirco Solé}

Universidade Estadual de Santa Cruz, Departamento de Ciências Biológicas, Vice-coordenado do Programa de Pós-Graduação em Zoologia, Rodovia Ilhéus/Itabuna, Km 16 (45662-000)

Salobrinho, Ilhéus - Bahia - Brasil

\section{Dr. Rajeev Raghavan}

Professor of Taxonomy, Kerala University of Fisheries \& Ocean Studies, Kochi, Kerala, India

\section{English Editors}

Mrs. Mira Bhojwani, Pune, India

Dr. Fred Pluthero, Toronto, Canad

Mr. P. Ilangovan, Chennai, India

Web Development

Mrs. Latha G. Ravikumar, ZOO/WILD, Coimbatore, India

\section{Typesetting}

Mr. Arul Jagadish, ZOO, Coimbatore, India

Mrs. Radhika, ZOO, Coimbatore, India

Mrs. Geetha, ZOO, Coimbatore India
Fundraising/Communications

Mrs. Payal B. Molur, Coimbatore, India

Subject Editors 2018-2020

Fungi

Dr. B. Shivaraju, Bengaluru, Karnataka, India

Dr. R.K. Verma, Tropical Forest Research Institute, Jabalpur, India

Dr. Vatsavaya S. Raju, Kakatiay University, Warangal, Andhra Pradesh, India

Dr. M. Krishnappa, Jnana Sahyadri, Kuvempu University, Shimoga, Karnataka, India

Dr. K.R. Sridhar, Mangalore University, Mangalagangotri, Mangalore, Karnataka, India

Dr. Gunjan Biswas, Vidyasagar University, Midnapore, West Bengal, India

\section{Plants}

Dr. G.P. Sinha, Botanical Survey of India, Allahabad, India

Dr. N.P. Balakrishnan, Ret. Joint Director, BSI, Coimbatore, India

Dr. Shonil Bhagwat, Open University and University of Oxford, UK

Prof. D.J. Bhat, Retd. Professor, Goa University, Goa, India

Dr. Ferdinando Boero, Università del Salento, Lecce, Italy

Dr. Dale R. Calder, Royal Ontaro Museum, Toronto, Ontario, Canada

Dr. Cleofas Cervancia, Univ. of Philippines Los Baños College Laguna, Philippines

Dr. F.B. Vincent Florens, University of Mauritius, Mauritius

Dr. Merlin Franco, Curtin University, Malaysia

Dr. V. Irudayaraj, St. Xavier's College, Palayamkottai, Tamil Nadu, India

Dr. B.S. Kholia, Botanical Survey of India, Gangtok, Sikkim, India

Dr. Pankaj Kumar, Kadoorie Farm and Botanic Garden Corporation, Hong Kong S.A.R., China

Dr. V. Sampath Kumar, Botanical Survey of India, Howrah, West Bengal, India

Dr. A.J. Solomon Raju, Andhra University, Visakhapatnam, India

Dr. Vijayasankar Raman, University of Mississippi, USA

Dr. B. Ravi Prasad Rao, Sri Krishnadevaraya University, Anantpur, India

Dr. K. Ravikumar, FRLHT, Bengaluru, Karnataka, India

Dr. Aparna Watve, Pune, Maharashtra, India

Dr. Qiang Liu, Xishuangbanna Tropical Botanical Garden, Yunnan, China

Dr. Noor Azhar Mohamed Shazili, Universiti Malaysia Terengganu, Kuala Terengganu, Malaysia

Dr. M.K. Vasudeva Rao, Shiv Ranjani Housing Society, Pune, Maharashtra, India

Prof. A.J. Solomon Raju, Andhra University, Visakhapatnam, India

Dr. Mandar Datar, Agharkar Research Institute, Pune, Maharashtra, India

Dr. M.K. Janarthanam, Goa University, Goa, India

Dr. K. Karthigeyan, Botanical Survey of India, India

Dr. Errol Vela, University of Montpellier, Montpellier, France

Dr. P. Lakshminarasimhan, Botanical Survey of India, Howrah, India

Dr. Larry R. Noblick, Montgomery Botanical Center, Miami, USA

Dr. K. Haridasan, Pallavur, Palakkad District, Kerala, India

Dr. Analinda Manila-Fajard, University of the Philippines Los Banos, Laguna, Philippines

Dr. P.A. Sinu, Central University of Kerala, Kasaragod, Kerala, India

Dr. Afroz Alam, Banasthali Vidyapith (accredited A grade by NAAC), Rajasthan, India

Dr. K.P. Rajesh, Zamorin's Guruvayurappan College, GA College PO, Kozhikode, Kerala, India

Dr. David E. Boufford, Harvard University Herbaria, Cambridge, MA 02138-2020, USA

Dr. Ritesh Kumar Choudhary, Agharkar Research Institute, Pune, Maharashtra, India

Dr. Navendu Page, Wildlife Institute of India, Chandrabani, Dehradun, Uttarakhand, India

\section{Invertebrates}

Dr. R.K. Avasthi, Rohtak University, Haryana, India

Dr. D.B. Bastawade, Maharashtra, India

Dr. Partha Pratim Bhattacharjee, Tripura University, Suryamaninagar, India

Dr. Kailash Chandra, Zoological Survey of India, Jabalpur, Madhya Pradesh, India

Dr. Ansie Dippenaar-Schoeman, University of Pretoria, Queenswood, South Africa

Dr. Rory Dow, National Museum of natural History Naturalis, The Netherlands

Dr. Brian Fisher, California Academy of Sciences, USA

Dr. Richard Gallon, llandudno, North Wales, LL30 1UP

Dr. Hemant V. Ghate, Modern College, Pune, India

Dr. M. Monwar Hossain, Jahangirnagar University, Dhaka, Bangladesh

Mr. Jatishwor Singh Irungbam, Biology Centre CAS, Branišovská, Czech Republic.

Dr. Ian J. Kitching, Natural History Museum, Cromwell Road, UK

Dr. George Mathew, Kerala Forest Research Institute, Peechi, India

For Focus, Scope, Aims, and Policies, visit https://threatenedtaxa.org/index.php/JoTT/aims_scope
For Article Submission Guidelines, visit https://threatenedtaxa.org/index.php/JoTT/about/submissions
For Policies against Scientific Misconduct, visit https://threatenedtaxa.org/index.php/JoTT/policies_various

continued on the back inside cover 


\title{
Utilization of home garden crops by primates and current status of human-primate interface at Galigamuwa Divisional Secretariat Division in Kegalle District, Sri Lanka
}

\author{
Charmalie Anuradhie Dona Nahallage ${ }^{1}$ (D), Dahanakge Ayesha Madushani Dasanayake ${ }^{2}(\mathbb{D})$ \\ Dilan Thisaru Hewamanna ${ }^{3}$ [D \& Dissanayakalage Tharaka Harshani Ananda ${ }^{4}$ (i)
}

\author{
${ }^{1}$ Centre for Multidisciplinary Research, 1,2,3,4 Department of Anthropology, \\ Faculty of Humanities and Social Sciences, University of Sri Jayewardenepura, Gangodawila, Nugegoda, 10250, Sri Lanka. \\ ${ }^{1}$ chamalie@sjp.ac.lk (corresponding author), ${ }^{2}$ madushaniayesha150@gmail.com, ${ }^{3}$ dilanthisaru@gmail.com, ${ }^{4}$ tharakaananda@sjp.ac.lk
}

\begin{abstract}
Many humans coexist with non-human primates (NHP), and as human populations have increased so have the pressures on natural habitats. For example, deforestation results in habitat loss and food scarcity for NHPs. In response, NHPs sometimes enter human habitats in search of food, which can result in negative interactions between humans and NHPs. This study focused on human-NHP interactions in three Grama Niladhari divisions in Kegalle District, Sri Lanka. We used interviewer-administered structured questionnaires to collect data from 500 randomly selected informants. The majority stated that they could not obtain sufficient harvests from home gardens for their own consumption owing to crop damage and losses caused largely by NHPs and other wild animals. This has led many people to abandon home gardening. Toque Macaques caused the most damage to crops, followed by Wild Boars, porcupines, and Purplefaced Leaf Langurs. Damage was caused to coconuts, vegetables, bananas, and yams. NHPs also caused property damage, with Toque Macaques causing more damage than langurs. People commonly used firecrackers, catapults and air rifles, and wore wooden or plastic face masks, in attempts to control crop damage by NHPs, with little success. People are of the opinion that the NHPs should be relocated to other forested areas or sterilized to control their numbers. In conclusion, to address the issues pertaining to human-primate interactions in terms of conflict due to crop utilization of primates, an integrated management plan should be developed in cooperation with the relevant stakeholders.
\end{abstract}

Keywords: Crop raiding, deforestation and habitat loss, economic loss, forest edge home gardens, human-primate conflict, integrated management plan, Macaca sinica, Semnopithecus vetulus.

Abbreviations: DSD-Divisional Secretariat Division | GN divisions-Grama Niladhari divisions | NHP-Non-human primate.

Editor: Honnavalli N. Kumara, Salim Ali Centre for Ornithology and Natural History, Coimbatore, India. D Date of publication: 26 January 2022 (online \& print)

Citation: Nahallage, C.A.D., D.A.M. Dasanayake, D.T. Hewamanna \& D.T.H. Ananda (2022). Utilization of home garden crops by primates and current status of human-primate interface at Galigamuwa Divisional Secretariat Division in Kegalle District, Sri Lanka. Journal of Threatened Taxa 14(1): 20478-20487. https://doi. org/10.11609/jott.7560.14.1.20478-20487

Copyright: @ Nahallage et al. 2022. Creative Commons Attribution 4.0 International License. JoTT allows unrestricted use, reproduction, and distribution of this article in any medium by providing adequate credit to the author(s) and the source of publication.

Funding: This research was funded under the mini research grants of the Multidisciplinary Research Centre of the Faculty of Humanities and Social Sciences, University of Sri Jayewardenepura.

Competing interests: The authors declare no competing interests.

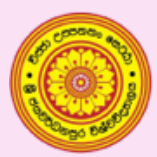

Author details: ChARMALIE ANURADHIE Dona NAHALLAge holds a Bachelor of Science in Zoology, Master of Science and Doctor of Science in Primatology from Primate Research Institute, Kyoto University, Japan. She is currently the head and conducts research on primate phylogeography and human-primate interactions in Sri Lanka. DAHANAKGE AYESHA MADUSHANI DASANAYAKE holds a Bachelor of Arts honours degree in Anthropology. She conducted a research on human-primate interactions for her undergraduate dissertation and currently awaiting to get registered for a Master of Philosophy degree to pursue her research interest on human-primate interactions. DILAN THISARU HEWAMANNA holds a Bachelor of Arts honours degree in Anthropology. He conducted a research on humanprimate interactions for his undergraduate dissertation and currently awaiting to get registered for a MPhil degree to pursue his research interest on the same. Dissanayakalage Tharaka HARSHANI ANANDA holds a Bachelor of Arts honours degree in Anthropology and a PhD in Anthropology from the University of Sri Jayewardenepura. She is currently a lecturer and conducts research on human variation and primatology.

Author contributions: CADN wrote the manuscript and DTHA, DAMD, and KKDTH contributed to data entering, analysis, and reviewing of the manuscript. DAMD, KKDH, and CADN collected field data.

Acknowledgements: The authors thank the dean of the Faculty of Humanities and Social Sciences, University of Sri Jayewardenepura and the director of the Multidisciplinary Research Center for their support. This research was funded under the mini research grants of the Multidisciplinary Research Centre of the Faculty of Humanities and Social Sciences. Also, we are grateful to the reviewers for the constructive suggestions and recommendations. The manuscript benefitted greatly from the inputs of the reviewers. We also thank Prof. M.G. Lalith Ananda for reading through the manuscript and correcting the language errors. 


\section{INTRODUCTION}

Humans, macaques, and langurs are members of the sub-order Anthropoidea in the Order Primates. The three species share many physiological, anatomical, and behavioral characteristics and thus have similar requirements to sustain themselves. As a result, when they share the same environment a variety of interactions between them become inevitable. Sometimes these interactions have negative impacts on species when they share similar food resources (Houle 1997; Peiman \& Robinson 2010). The intensity of the interactions increases with the similarity of shared resources, creating competition within or between species, which at times can be detrimental to one or both.

Non-human primates and humans maintain both positive and negative interactions. The positive interactions include deploying primates for economically beneficial activities such as harvesting coconuts, as can be seen in Thailand and also as performers to entertain humans (Nahallage \& Huffman 2013; Nahallage 2019). In both instances, humans gain economic benefit by employing primates in various activities, which in turn creates a positive attitude towards them. Most crucial for the survival of the primates and their conservation is mitigating adverse interactions that create negative attitudes toward primates, primarily in the form of human and non-human primate competitions over common resources.

One of the main reasons for escalating humanprimate negative interactions in Sri Lanka is the loss of natural primate habitat due to various development projects (Nahallage et al. 2008; Cabral et al. 2018; Dittus et al. 2019). Primates become isolated in small forest patches because of the fragmentation of forests they inhabit, which leads to an increase in competition for food and space. When resources become depleted in the natural habitat, primates frequent villages in search of food, which intensifies human-primate interactions (Dela 2007; Rudran 2007; Nahallage et al. 2008; Dittus 2012; Rudran \& Kotagama 2016, Dittus et al. 2019; Nahallage 2019). Other reasons monkeys are attracted to nearby settlements include improper garbage disposal, feeding by humans, cultivation of large-scale cash crops, and scarcity of food \& water in the natural habitats during the dry season (Dittus et al. 2019).

In Sri Lanka, the three diurnal primate species are mainly involved in human-primate interactions: Toque Macaquea Macaca sinica, Purple-faced Leaf Langurs Semnopithecus vetulus and Gray Langurs Semnopithecus priam (Nahallage \& Huffman 2013; Dittus et al. 2019).
No conflicts have been reported with two resident nocturnal Loris spp., which have little interaction with humans. Macaques are sociable animals that interact frequently with humans and prefer to stay close to human settlements, while langurs prefer more natural habitats and foods (Nahallage \& Huffman 2013; Dittus et al. 2019; Nahallage 2019). Purple-faced Leaf Langurs are strictly arboreal folivores and have the least interaction with humans in many places. This relationship, however, varies in different parts of the country (Rudran 1973, 2007; Dela 2007; Dittus 2012; Dittus et al. 2019; Nahallage 2019), with Purple-faced Leaf Langurs in the Western Province considered the most prominent species living close to humans causing crop and property damage. Food selection by Gray Langurs depends on their habitat; in natural environments they depend mainly on plant material, while those in urban environments and temple areas tend to consume food given to them by pilgrims, such as leftover offerings (Nahallage et al. 2008; Nahallage \& Huffman 2013; Dittus et al. 2019). During periods of food scarcity, both Gray Langurs and Toque Macaques obtain food forcibly from people or directly from houses or shops, leading to intense human-primate negative interactions.

Human-primate interactions is not a recent occurrence in the country. Robert Knox, an English traveler who was imprisoned on the island by the Kandyan King but allowed to live in various places freely for about 20 years, described how macaques invaded corn fields and home gardens despite their being heavily guarded (Knox 1681). There were even folk poems written regarding the crop raiding of primates (Ananda 2000). At present, crop raiding occurs in all 25 districts of the country. Crop raiding by primates generally depends on the types of crops grown, seasonality, distance to the village from the forest, availability of natural foods, and the methods of crop guarding (Hill 2000; Marchal \& Hill 2009; Fungo 2011). In Sri Lanka, macaques inflict more damage to crops than langurs, but all are considered pests to varying degrees in the provinces where they are found (Nahallage at al. 2008; Nahallage \& Huffman 2013; Prasad et al. 2016; Nahallage 2019; Dittus et al. 2019). In places where all three diurnal primates exist, Toque Macaques damage crops the most, followed by Gray Langurs (Nahallage et al. 2008), however, in some parts of the North Central Province, Gray Langurs cause more damage than Toque Macaques (Perera \& Vandercone 2016).

The main objective of this study was to determine the present status of human-primate interactions in relation to home garden crop damage in selected 


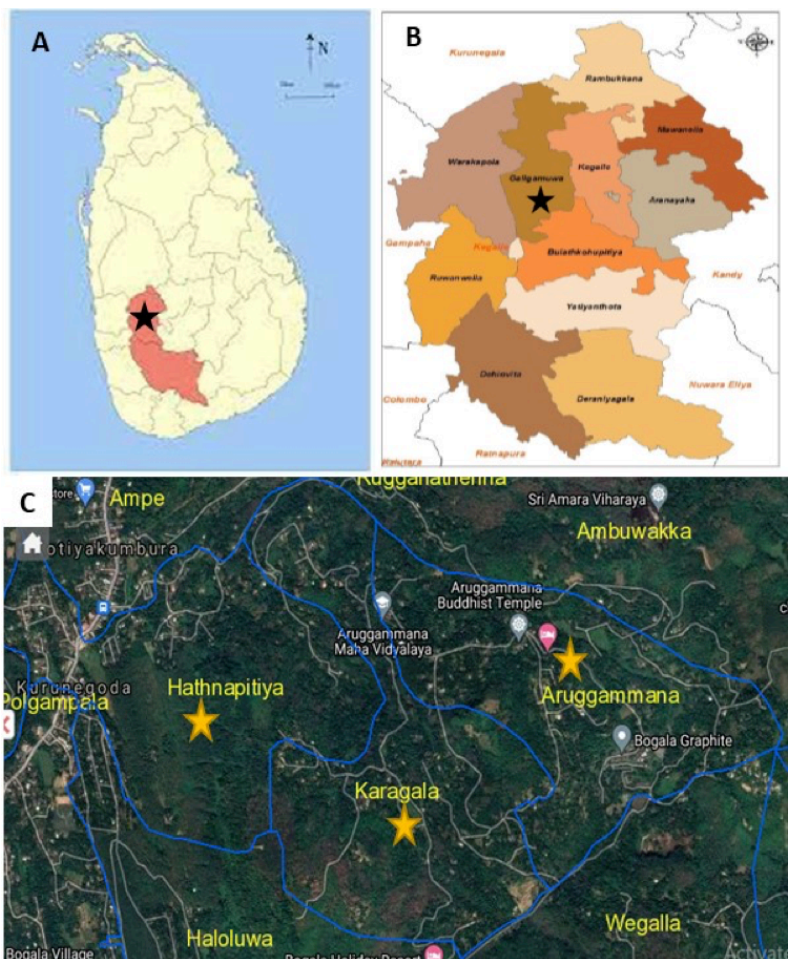

Image 1. Study area: A-Kegalle District | B-Galigamuwa Divisional Secretariat Division | C-Three GN divisions (Hathnapitiya, Karagala, and Aruggammana).

areas in Kegalle District. This study looks into the wild animals in the selected study area and their impact on home garden crops. Home garden cultivations are very important to these low-income rural villagers, as they supply food to meet their daily needs and allow them to earn additional income by selling the excess harvest. The specific objectives were to find out the extent of crop damage by non-human primates and other wild animals, the types of crops that are mostly affected by crop raiding primates, the types of property damage they do, the control measures used by humans to prevent or reduce crop damage and the people's perception of the type of mitigative actions that should be taken to control conflicts.

\section{METHODS}

The selected study area was in the Galigamuwa Divisional Secretariat Division (DSD) in the Kegalle district, Sabaragamuwa Province. Out of the 51 Grama Niladhari Divisions (GN divisions), three GN divisions namely Aruggammana, Hathnapitiya, and Karagala were purposely selected as they recorded higher incidents of human primate interactions according to the
Galigamuwa DSD office (Image 1). This was a descriptive cross-sectional study.

Galigamuwa DSD is located in the wet zone, and receives more than $2,500 \mathrm{~mm}$ annual average rainfall, and has a mean temperature of $22-27{ }^{\circ} \mathrm{C}$. Agriculture is the main economic sector in the area. The land extent is $127 \mathrm{~km}^{2}$. Hapudeniya is the highest parish in the division at $366 \mathrm{~m}$ above sea level and the lowest is Helamada at $27 \mathrm{~m}$. The two primate sub-species present in the area are Macaca sinica aurifrons and Semnopithecus vetulus nestor.

\section{Location of the home gardens}

Of the home gardens, $48 \%$ in Hathnapitiya, 32\% in Aruggammana, and $80 \%$ in Karagala are located less than $50 \mathrm{~m}$ from the forest. Most of the home gardens in Karagala are located at the edge of the forest. Compared to Karagala GN divisions, most home gardens in Hathnapitiya and Aruggammana are located more than $100 \mathrm{~m}$ away from the forest edge (52\% in Hathnapitiya and $68 \%$ in Aruggammana).

A total of 500 households were surveyed (Table 1). The electoral registers lists were obtained from Grama Niladhari officers in the respective GN Divisions to randomly select the houses for the survey. In instances where the people were not willing to participate in the survey or had vacated these houses, the next address was selected. The study was conducted between October and December 2018.

We used an interviewer-administered questionnaire method to collect data from each household for the survey. We obtained the required information from the head of the house or an adult (wife, parents or inlaws of the head of the house) present in each house at the time the data collectors visited the house. The structured questionnaire included 19 closed and open-ended questions on such topics as: occupation of the informant; the size of the home garden; types of crops cultivated; average monthly income; types of wild animals frequenting the home garden; the types of crops consumed or damaged by the animals; the extent of property damage; the measures taken to control the damage, and the peoples' perceptions on

Table 1. Selected sample sizes in each GN Division.

\begin{tabular}{|l|c|c|}
\hline GN Division & $\begin{array}{c}\text { Total No. of houses in } \\
\text { each GN Division }\end{array}$ & $\begin{array}{c}\text { Number of houses } \\
\text { surveyed }\end{array}$ \\
\hline Aruggammana & 368 & 214 \\
\hline Hathnapitiya & 303 & 136 \\
\hline Karagala & 232 & 150 \\
\hline
\end{tabular}


how to control the damage caused by primates. Before collecting these data, we explained the purpose of the survey to the participants. Those who were willing to provide information were then given enough time to ask questions regarding the survey, and their written consent was obtained with a signature at the bottom of each questionnaire. On average, it took about 20 minutes to fill the questionnaire. In addition, we conducted field observations as well.

The collected data were entered into a Microsoft Excel sheet and analyzed using SPSS package (version 16).

\section{RESULTS}

\section{Occupation of the informants}

Except for Aruggammana GN Division, the majority of the informants were housewives (Table 2). Aruggammana and Karagala have more self-employed informants than Hathnapitiya.

\section{Size of the Home Garden}

All three GN divisions had many home gardens of less than 1.0 acre $\left(4047 \mathrm{~m}^{2}\right)$ in size, representing 93\% of home gardens in Hathnapitiya, 66\% in Aruggammana and $82 \%$ in Karagala (Table 3). When compared with the other two GN divisions, 33\% of the home gardens in Aruggammana were larger, ranging from 1 to 5 acres.

\section{Types of crops cultivated in the home gardens}

The most common home gardening crops grown in all three GN divisions were coconuts (15\%), Jack fruits $(13 \%)$, areca nuts $(13 \%)$, pepper $(10 \%)$, and bananas (9\%). More people grow coconuts in Hathnapitiya than Aruggammana and Karagala, while tea was cultivated more in Aruggammana and Karagala areas (Table 4).

\section{Economic loss due to crop damage}

During the time of data collection, the informants of Hathnapitiya (50\%), Aruggammana (23\%), and Karagala (21\%) stated that they could not get sufficient harvest from home gardens for their consumption. All of the Hathnapitiya, 94\% of Aruggammana, and 62\% of Karagala respondents informed us that at present they cannot get sufficient additional income from home garden crops. Of the informants, $4 \%$ from Aruggammana and $33 \%$ from Karagala said that they get less than SLR 10,000 income per month and only $1 \%$ of Aruggammana and $6 \%$ of Karagala informants said they receive more than SLR 10,000 income per month (Table 05).

\section{Reasons for not engaging in cultivation}

In all three GN divisions people gave various reasons for not cultivating crops in home gardens, however, the majority of the informants stated the main reason was crop damage caused by wild animals, mainly primates (Hathnapitiya 87\%, Aruggammana 92\%, Karagala 94\%). The other reasons were not enough manpower (Hathnapitiya 5\%, Aruggammana 4\%, Karagala 6\%), inadequate land area (Hathnapitiya 5\%, Aruggammana $2 \%$ ), inadequate water (Hathnapitiya $2 \%$, Aruggammana $2 \%)$, and infertility of the soil (Hathnapitiya 1\%).

\section{Animals responsible for crop damage}

In all three respective $\mathrm{GN}$ divisions, the main species identified as responsible for crop damage were Toque Macaques, Wild Boars, porcupines, and Purple-faced Leaf Langurs (Table 6).

According to informants the NHPs frequent home gardens irrespective of the time of the day (Table 7).

\section{The crops utilized by animals}

The three main crops that the NHP utilized most were coconuts, bananas, and different types of yams. In addition, they consumed garden vegetables including brinjal Solanum melongina, winged beans Psophocarpus tetragonolobus, snake gourds Trichosanthes cucumerina, long beans Vigna unguiculata, lady'sfingers Abelmoschus esculentus (Table 08).

\section{Consequences of crop damage by animals}

Decreases in harvests (Hathnapitiya 59\%, Aruggammana 51\%, Karagala 43\%) and income (Hathnapitiya 16\%, Aruggammana 22\%, Karagala 28\%) were the main effects of crop damage by animals. As a result, people have discontinued home garden cultivation (Hathnapitiya 25\%, Aruggammana 26\%, Karagala 27\%), and some have abandoned all or parts of their lands as they cannot control animal visits (Aruggammana 1\%, Karagala 2\%).

\section{Property damage caused by Toque Macaques and langurs}

In addition to crop damage, Toque Macaques and langurs also damage property. Toque Macaques caused the most property damage by entering houses and damaging household furniture and utensils (Table 9).

Langurs were not reported to cause much property damage, which was only reported in $2 \mathrm{GN}$ divisions where langurs caused damage to roofs (Table 9). There were no reports of other wild animals causing property damage. 
Table 2. Occupation of the informants in each GN divisions.

\begin{tabular}{|c|c|c|c|c|c|c|}
\hline \multirow{2}{*}{ Occupation } & \multicolumn{2}{|c|}{ Hathnapitiya } & \multicolumn{2}{|c|}{ Aruggammana } & \multicolumn{2}{|c|}{ Karagala } \\
\hline & Frequency & $\%$ & Frequency & $\%$ & Frequency & $\%$ \\
\hline No occupation (housewives) & 67 & 49 & 54 & 25 & 72 & 48 \\
\hline Government sector & 27 & 20 & 60 & 28 & 21 & 14 \\
\hline Private sector & 24 & 18 & 33 & 15 & 21 & 14 \\
\hline Commercial farming & 3 & 2 & 1 & 0.5 & 2 & 1 \\
\hline Self-employment & 13 & 10 & 66 & 31 & 31 & 21 \\
\hline Security service & 2 & 2 & 0 & 0 & 3 & 2 \\
\hline Total & 136 & 100 & 214 & 100 & 150 & 100 \\
\hline
\end{tabular}

Table 3. Size of the Home garden.

\begin{tabular}{|c|c|c|c|c|c|c|}
\hline \multirow{2}{*}{$\begin{array}{l}\text { GN Division } \\
\text { Size of home garden }\end{array}$} & \multicolumn{2}{|c|}{ Hathnapitiya } & \multicolumn{2}{|c|}{ Aruggammana } & \multicolumn{2}{|c|}{ Karagala } \\
\hline & $\mathrm{N}$ & Valid Percent & N & Valid Percent & N & Valid Percent \\
\hline Between 1.1 to 5 acres $\left(4,047-20,234 \mathrm{~m}^{2}\right)$ & 5 & 5 & 63 & 33 & 22 & 15 \\
\hline More than 5 acres (more than 20,234 $\mathrm{m}^{2}$ ) & 3 & 3 & 3 & 2 & 4 & 3 \\
\hline Not responded & 25 & & 22 & & 8 & \\
\hline Total & 136 & & 214 & & 150 & \\
\hline
\end{tabular}

\section{Methods used by people to control crop damage by primates}

Methods used to prevent primates from entering gardens are described in Table 10. The most common methods used to chase away monkeys were firecrackers, catapults, and wooden or plastic face masks. During the study period some people had been using air rifles to chase monkeys from their gardens, a new addition to control methods.

Recommendations to control crop damage by primates.

Suggestions by informants to reduce primate crop damage were: $46 \%$ wanted monkeys relocated into other areas; $30 \%$ suggested sterilizing them to control population growth; 9\% think government authorities should provide mitigative strategies; $10 \%$ wanted permission to use guns; and $5 \%$ suggested killing monkeys (5\%).

\section{DISCUSSION}

Crop damage by primates and other wild animals

Although most studies on human-primate negative interactions were concentrated on commercial farming, the present study mainly focused on the human-primate interactions occurring due to crop raiding of primates on home gardens. In the semi urban and rural areas in Sri Lanka, local people grow crops such as coconuts, banana, jack fruits, areca nuts, vegetables, and different kinds of spices in their home gardens to meet their daily food needs. Before the intensification of crop raiding, people have been able to obtain their daily food needs and an additional income from their home gardens. This way, they do not have to spend much money to buy food items. Home gardening has been a very important means of maintaining their economic status for generations.

However, at present, people are facing many problems as wild animals have started to frequently raid home gardens to take food (Nahallage \& Huffman 2013; Cabral et al. 2016; Dela et al. 2016; Perera \& Vandercone 2016; Prasad et al. 2016; Rudran \& Kotagama 2016; Cabral et al. 2018; Dittus et al. 2019). The majority of home gardens in the study area are comparatively small (less than 1 acre) and primates cause extensive damage to these small-scale garden cultivations. The majority of the informants of all three $\mathrm{GN}$ divisions complained that they cannot get adequate harvest for their daily needs and that they had to buy coconuts and vegetables from the market. This is creating a new economic burden 
Table 4. Types of home garden crops cultivated in the respective GN divisions.

\begin{tabular}{|c|c|c|c|}
\hline Types of crops & $\begin{array}{l}\text { Hathanapitiya } \\
\text { (\%) }\end{array}$ & $\begin{array}{l}\text { Aruggammana } \\
(\%)\end{array}$ & Karagala (\%) \\
\hline Coconut & 18 & 14 & 13 \\
\hline Banana & 12 & 9 & 7 \\
\hline Jack Fruit & 11 & 14 & 13 \\
\hline Areca nut & 11 & 13 & 13 \\
\hline Pepper & 8 & 11 & 10 \\
\hline Avocado & 5 & 6 & 4 \\
\hline Vegetables & 5 & 1 & 3 \\
\hline Tea & 4 & 8 & 11 \\
\hline Clove & 3 & 8 & 6 \\
\hline Rubber & 2 & 3 & 3 \\
\hline Yams & 2 & 2 & 3 \\
\hline Pineapple & 1 & 1 & 1 \\
\hline Durian & 1 & 2 & 1 \\
\hline Breadfruit & 1 & 1 & 1 \\
\hline Magnus & 1 & 0 & 2 \\
\hline Betel & 1 & 1 & 2 \\
\hline Nutmeg & 0 & 0 & 1 \\
\hline Cardamon & 0 & 0 & 0 \\
\hline Other & 12 & 7 & 7 \\
\hline
\end{tabular}

as these people are in the low-income group and face economic hardships because of the crop damage. The crops that are mainly affected by primates and other wildlife were coconuts, bananas, and vegetables, the key food varieties of these communities. The animals that are causing considerable damage to coconuts were Toque Macaques in all three study areas. According to informants, macaques visit the gardens daily and drop the young coconuts to the ground and also peel off the mature coconuts and eat the soft flesh inside. This way, many immature nuts get destroyed resulting in a decrease in the total harvest. During the field visits the authors were able to observe these young coconuts piled up by the side of the garden. Furthermore, the macaque visits were not limited to a particular time of the day, and they stayed for a long time which escalated the scale of damage. This situation has led some people to abandon growing and tending coconut trees, as they believe that it was a waste of time and money. At present, people are buying coconuts from the nearby markets for their own consumption. Coconuts have been one of their main additional income generating crops. Therefore, currently the people not only have to spend money to buy coconuts but have lost their additional income as well. However, Purple-faced Leaf Langurs were not
Table 5. Monthly income obtained from home gardening.

\begin{tabular}{|l|c|c|c|c|c|c|}
\hline \multirow{2}{*}{ GN Division } & \multicolumn{2}{|c|}{ Hathnapitiya } & \multicolumn{2}{c|}{ Aruggammana } & \multicolumn{2}{|c|}{ Karagala } \\
\hline \multirow{2}{*}{ Income } & \multicolumn{2}{|c|}{ Present } & \multicolumn{2}{|c|}{ Present } & \multicolumn{2}{c|}{ Present } \\
\cline { 2 - 8 } & $\mathrm{N}$ & $\%$ & $\mathrm{~N}$ & $\%$ & $\mathrm{~N}$ & $\%$ \\
\hline No income & 136 & 100 & 202 & 94 & 92 & 62 \\
\hline Less than SLR 10,000 & 0 & 0 & 9 & 4 & 49 & 32 \\
\hline More than SLR 10,000 & 0 & 0 & 3 & 2 & 9 & 6 \\
\hline Total & 136 & 100 & 214 & 100 & 150 & 100 \\
\hline
\end{tabular}

Table 6. Animals that are responsible for crop damage.

\begin{tabular}{|l|c|c|c|}
\hline GN Division & $\begin{array}{c}\text { Hathnapitiya } \\
\text { (\%) }\end{array}$ & $\begin{array}{c}\text { Aruggammana } \\
\text { (\%) }\end{array}$ & $\begin{array}{c}\text { Karagala } \\
\text { (\%) }\end{array}$ \\
\hline Toque Macaque & 40 & 34 & 29 \\
\hline Wild Boar & 25 & 30 & 25 \\
\hline Porcupine & 14 & 23 & 21 \\
\hline Purple-faced Leaf Langur & 18 & 7 & 16 \\
\hline Giant Squirrel & 1 & 2 & 3 \\
\hline Rat & 0 & 1 & 1 \\
\hline Snail & 0 & 1 & 1 \\
\hline Coconut Beetle & 1 & 0 & 0 \\
\hline Peacock & 1 & 1 & 1 \\
\hline Parrot & 0 & 0 & 1 \\
\hline Grey Hornbill & 0 & 0 & 1 \\
\hline Other & 0 & 1 & 1 \\
\hline
\end{tabular}

Table 7. The time of animal visits to home gardens.

\begin{tabular}{|l|c|c|c|}
\hline GN Division & $\begin{array}{c}\text { Hathnapitiya } \\
\text { (\%) }\end{array}$ & $\begin{array}{c}\text { Aruggammana } \\
\text { (\%) }\end{array}$ & Karagala (\%) \\
\hline Moring only & 6 & 1 & 3 \\
\hline Evening only & 6 & 1 & 3 \\
\hline Night only & 15 & 0 & 5 \\
\hline Anytime of the day & 67 & 96 & 82 \\
\hline Cannot say & 6 & 2 & 7 \\
\hline
\end{tabular}

reported to damage coconut trees in the study area.

The other home garden crop that was mostly affected by the primates was banana. Both Toque Macaques and Purple-faced Leaf Langurs raid banana trees. They not only eat the banana fruits but damage the trees which reduces future harvests as well. Of the two primates, langurs consume the banana most. Informants stated that langurs mostly consume the unripe fruit while the macaques eat the ripe yellow fruit. However, in a separate study, Purple-faced Leaf Langurs were reported to eat ripe fruits in some districts of the country (Dela 2012). Other than bananas, both primate species 
Table 8. The crops utilized by animals.

\begin{tabular}{|c|c|c|c|}
\hline GN Division & $\begin{array}{c}\text { Hathnapitiya } \\
\text { (\%) }\end{array}$ & $\begin{array}{c}\text { Aruggammana } \\
\text { (\%) }\end{array}$ & Karagala (\%) \\
\hline Coconut & 22 & 29 & 21 \\
\hline Vegetables & 19 & 4 & 9 \\
\hline Banana & 15 & 12 & 12 \\
\hline $\begin{array}{l}\text { Yams (kiri ala, } \\
\text { casava) }\end{array}$ & 12 & 16 & 15 \\
\hline Pepper & 4 & 9 & 10 \\
\hline Areca nut & 3 & 6 & 8 \\
\hline Jack Fruit & 4 & 6 & 5 \\
\hline Pineapple & 2 & 1 & 1 \\
\hline Tea & 1 & 4 & 5 \\
\hline Avocado & 1 & 1 & 1 \\
\hline Rubber & 1 & 2 & 1 \\
\hline Bread Fruit & 1 & 1 & 1 \\
\hline Betel & 1 & 2 & 3 \\
\hline Durian & 1 & 1 & 0 \\
\hline Nutmeg & 1 & 0 & 1 \\
\hline Cardamom & 1 & 0 & 0 \\
\hline Clove & 0 & 0 & 1 \\
\hline Other & 11 & 6 & 6 \\
\hline
\end{tabular}

were reported to consume jack fruit, pineapple, other available fruits, vegetables, and yams, depending on the season. In general, macaques cause more damage to crops than langurs in all the districts in the country. The omnivorous macaques consume a diverse range of food items including fruits, leaves, bark, flowers, seeds, roots, cereals, insects, other invertebrates, eggs, small mammals, birds, and food prepared by humans. Owing to these diverse food habits and larger group sizes, macaques can adapt to any environmental condition and hence cause more damage than the two langur species. According to the study conducted by Prasad et al. (2016), of the complaints received by the Wildlife Department, $54 \%$ were against macaques and $29 \%$ against Purplefaced Leaf Langurs. Out of these, $70 \%$ were related to crop damages; however, the primate species responsible for crop damage was different in different parts of the country. According to the study of Perera \& Vandercone (2016), in Mihintale Kaludiyapokuna forest edge farms, Gray Langurs and Toque Macaques were responsible for $78 \%$ and $22 \%$ of the reported crop damages, respectively. Purple-faced Leaf Langurs were not recorded to damage crops in that area. A study carried out by Dittus et al. (2019) in Polonnaruwa reported similar results indicating that macaques and Gray Langurs were responsible for human-primate interactions rather than the Purple-
Table 9. Types of property damage caused by Toque Macaques and Purple-faced Leaf Langur.

\begin{tabular}{|c|c|c|c|}
\hline Type of Damage & $\begin{array}{c}\text { Hathnapitiya } \\
\text { (\%) }\end{array}$ & $\begin{array}{l}\text { Aruggammana } \\
(\%)\end{array}$ & Karagala (\%) \\
\hline \multicolumn{4}{|l|}{ Macaques } \\
\hline $\begin{array}{l}\text { Damage household } \\
\text { goods }\end{array}$ & 15 & 25 & 27 \\
\hline $\begin{array}{l}\text { Consume foods } \\
\text { that are inside the } \\
\text { house }\end{array}$ & 35 & 31 & 37 \\
\hline $\begin{array}{l}\text { Defecate inside the } \\
\text { house }\end{array}$ & 25 & 22 & 23 \\
\hline Damage roofs & 24 & 17 & 10 \\
\hline $\begin{array}{l}\text { Other types of } \\
\text { damages }\end{array}$ & 1 & 5 & 3 \\
\hline \multicolumn{4}{|c|}{ Purple-faced Leaf Langur } \\
\hline Damage roof & 15 & 1 & 0 \\
\hline No damage & 85 & 99 & 100 \\
\hline
\end{tabular}

Table 10. Methods used to reduce the crop damage by Toque Macaques.

\begin{tabular}{|l|c|c|c|}
\hline GN Division & $\begin{array}{c}\text { Hathnapitiya } \\
\text { (\%) }\end{array}$ & $\begin{array}{c}\text { Aruggammana } \\
\text { (\%) }\end{array}$ & Karagala (\%) \\
\hline Catapult & 21 & 33 & 30 \\
\hline Firecrackers & 42 & 36 & 30 \\
\hline Masks & 10 & 7 & 10 \\
\hline Hanging tin cans & 1 & 0 & 0 \\
\hline Nets to cover crops & 2 & 3 & 6 \\
\hline Boards & 1 & 1 & 6 \\
\hline Shouting & 11 & 4 & 4 \\
\hline Black cloth & 1 & 1 & 1 \\
\hline Air rifles & 0 & 1 & 1 \\
\hline Use of dogs & 0 & 1 & 1 \\
\hline Clapper board & 0 & 1 & 10 \\
\hline Others & 11 & 12 & \\
\hline
\end{tabular}

faced Leaf Langurs. In Western province, it is the Purplefaced Leaf Langurs that cause the most damage to home garden crops (Dela 2007; Rudran 2007; Nahallage et al. 2008; Cabral et al. 2016; Prasad et al. 2016; Nahallage 2019). The other factors that are responsible for crop damage are the availability of natural foods, the variety of crops grown, seasonality, distance from the forest and the people's perceptions (Hill 2005). According to some informants in Hathnapitiya GN division, the frequency of primate visits was less during the months of January to July as it was the fruiting season and monkeys could find food in the forests where they live.

In addition to primates, the other wild animal species that are responsible for crop damage in the study area are the two nocturnal mammals: the Wild 
Boars and porcupines. These animals mainly damage the vegetables and the yams that people grow. Next to macaques, Wild Boars caused the most damage to cultivations followed by porcupines. Most of the people in the three $\mathrm{GN}$ divisions have stopped cultivating home garden crops due to the crop damage caused by wildlife resulting in the decrease of the harvest and income as well.

In addition to crop damage, primates were the only wildlife species reported to damage property. Macaques were reported to have damaged the household goods such as pots, pans, plates, rice cookers, and furniture. When they are able to enter into a house in an unguarded moment, they consume the foods stored inside cupboards and racks, runaway with the cooked and other types of dry foods, defecate inside the house and damage roofs as well. Similar incidence was reported in Kandy district where macaques were responsible for taking food by force, damaged the roof, and damaged the infrastructure (Cabral et al. 2016). Compared to macaques, langurs cause less property damage and the only reported damage by the langurs ( $P F L$ - present study and Gray Langur - Dittus et al. 2019) was to roofs due to their large body size. In the study area, people used wire meshes and wood planks to cover their windows and spaces between the roof and the walls. This successfully cut down the multiple entry points of the monkeys to one's house (CN personal observation). This leaves the monkeys to come into the house either from the back or front door, which only the boldest ones would try.

\section{Methods used by people to reduce crop damage}

People believe that over the years the primate populations have increased and many now consider them as pests due to crop damage. The methods used by people in the study area to reduce primate crop damage were similar within the country as well as in other countries. The most common methods were the use of stones, firecrackers, shouting, and catapults to chase the primates away from their properties with very little success (Nahallage et al. 2008; Hill \& Webber 2010; Dittus et al. 2019). The monkeys get used to or learn to avoid these methods and with time the methods become less effective. People abstain from hunting, killing or poisoning monkeys due to their religious beliefs and most of the time are tolerant of their behaviors (Nahallage \& Huffman 2013), or they employ methods just to chase the monkeys from their home gardens. The people in the study area wear long black cloths with a wooden or plastic face mask and carry a stick to scare the monkeys, or point a gun shaped wooden stick at them.
This seems to work better compared to other methods. In the study area, the most effective technique was air rifles. The monkeys were afraid of them. However, since the air rifles were expensive most people cannot afford to buy them. In addition, people wrap thorny branches of jackal jujube Ziziphus oenoplia and lime Citrus aurantifolia around banana bunches or on the fronds to prevent monkeys from getting to the fruits or they cover the banana bunches with nylon nets or bags. To protect coconuts, they wrap aluminium sheets around coconut trees to prevent macaques climbing the trees. Further they sprinkle cow dung mixed with water on coconuts and the informants believed that macaques dislike the smell of cow dung. During a survey in the Northwestern province $\mathrm{CN}$ observed that in some coconut plantations, people covered the young coconut bunch with iron mesh so macaques could not reach the coconuts. However, the owner of the plantation informed this was both time consuming as well as costly and that they must increase the mesh size when the coconuts increase in size (CN personal observation). This is not practical to implement in large coconut estates. The use of dogs to chase the monkeys has not been much in practice in the present study areas. The most effective method the informants used to protect crop damage by wild boar was to cover the vegetable beds with sarees to keep the wild boars away. To protect the vegetables from porcupines, people sprinkled human hair around the vegetable beds. They reported that the porcupines dislike this and try to evade such vegetable beds. This method too was not practical in the long run because the hairs get blown away with the wind and the rain dampens it reducing its effectiveness.

\section{Mitigative actions to control the damage caused by monkeys}

To reduce the damage caused by primates to home garden crops, the majority of people wanted the monkeys to be relocated to another area or sterilized them to control population growth. Relocation of monkeys has detrimental effects to the monkeys if not managed properly. For the relocation to be effective, the monkeys have to be transported to a similar environment or ecological zone that they were used to. Otherwise, it will not be possible for them to adapt to the new environment successfully and will have trouble finding necessary food sources and might die of starvation. Therefore, effective post translocation monitoring mechanisms should be implemented. Further, translocation of monkeys who were used to living close to human settlements (and utilize human grown crops) to remote areas also will not 
be effective as the monkeys will go in search of nearby human habitats. Thus, relocation might temporarily solve the problem in one location but will spread the problem to other parts of the country (Nahallage 2019; Dittus et al. 2019).

Sterilization of the monkeys will be effective to some extent. Though sterilization requires manpower, veterinary expertise, and money, it is a permanent solution for population control (Jayalath \& Dangolla 2011). In addition, some countries use birth control as an effective strategy of fertility control (Shimizu 2012). This is most applicable to monkeys that are seasonal breeders, making the process reversible, allowing them to resume their normal cycles and normal pregnancies later. With further studies and investigations there is a high possibility to apply this method successfully in Sri Lanka as well.

Further, the informants want the government to take some initiatives for control and advise them on how they could best control the situation. So far, the authorities have not conducted awareness programs for the villagers. According to the discussions the authors had with the villagers during data collection and field visits, it was obvious that they do not know much about the primates in their area or even that the primate species are endemic to the country. Thus, it is important that the villagers understand the behaviors, life histories and the factors that drive these primates to the villages. This awareness would give them an insight into the issue and help them to act accordingly. During the field visits, intentional provision of food to primates and keeping primates as pets were not observed in the study area. However, garbage dumping sites and macaques feeding on garbage dumping sites were observed in all three divisions

Therefore, the authors recommend the following mitigative actions to control the situation; conduct awareness programs, introduce proper garbage disposal mechanisms, enrichment of the natural habitats of the primates and to facilitate long term research to gather more information.

\section{CONCLUSION}

For decades, scientists and primatologists across the world have been conducting research studies related to human primate interactions to find ways to minimize damage to both parties concerned, such as damage to crops and properties of humans and killing and wounding of primates. Though these studies provide many useful recommendations, none of them were able to provide plausible long-term solutions to mitigate this problem. Nahallage et al. (2018), proposed to use an integrated management plan (IMP) to minimize the damage to the conflicted parties. The integrated management plan is mainly based on the: a) biology and the behavior of the primate; b) occurrence and the level of damage; $c$ ) habitats; and d) interaction between the primates and the humans. With this method, the local authorities, with the help of the experts have to decide the control strategies for each of the above-mentioned components and select control methods that are suitable to local conditions and implement them with the cooperation of relevant stakeholders. However, future research is needed to test this plan with different primate species and under different environmental conditions.

\section{REFERENCES}

Ananda, P.A.S. (2000). Sinhala Janashruthiya saha sathwa lokaya. Godage Publishers, Colombo, $152 \mathrm{pp}$

Cabral, S.J., T. Prasad, T.P. Deeyagoda, S.N. Weerakkody, A. Nadarajah \& R. Rudran (2018). Investigating Sri Lanka's human-monkey conflict and developing a strategy to mitigate the problem. Journal of Threatened Taxa 10(3): 11391-11398. https://doi.org/10.11609/ jott.3657.10.3.11391-11398

Cabral, S.J., A.P. Sumanapala, R. Ratnayake, H.D. Jayasinghe, D.K. Weerakoon, S.W. Kotagama \& R. Rudran (2016). Distribution of Toque Macaques (Macaca sinica) and their impact on human lives in Kandy district of Sri Lanka. In: Proceedings of the $5^{\text {th }}$ Asian Primate Symposium, University of Sri Jayewardenepura, Sri Lanka, 46pp.

Dela, J.D.S. (2007). Seasonal food use strategies of Semnopithecus vetulus nestor, at Panadura and Piliyandala, Sri Lanka. International Journal of Primatology 28: 607-626. https://doi.org/10.1007/ s10764-007-9150-8

Dela, J.D.S. (2012). Western Purple-faced Langurs (Semnopithecus vetulus nestor) feed on ripe and ripening fruits in human-modified environments in Sri Lanka. International Journal of Primatology 33: 40-72. https://doi.org/10.1007/s10764-011-9538-8

Dela, J.D.S., U.K.G.K. Padmalal, A. Sathurusinghe \& A.S.S. Silva (2016). Bringing back Semnopithecus vetulus nestor from the living dead to the visibly thriving: Identification of threats and prescriptions. In: Proceedings of the $5^{\text {th }}$ Asian Primate Symposium, University of Sri Jayewardenepura, Sri Lanka, p. 51.

Dittus, W. (2012). Problems with pest monkeys: myths and solutions. Loris 26(3/4): 18-23.

Dittus, W.P.J., S. Gunathilake \& M. Felder (2019). Assessing public perceptions and solutions to human-monkey conflict from 50 years in Sri Lanka. Folia Primatologica 90: 89-108. https://doi. org/10.1159/000496025

Fungo, B. (2011). A review of crop raiding around protected areas: Nature, control and research gaps). Environmental Research Journal 5(2): 87-92.

Hill, C.M. (2000). A conflict of interest between people and baboons: crop raiding in Uganda. International Journal of Primatology 21: 299-315. https://doi.org/10.1023/A:1005481605637

Hill, C.M. (2005). People, crop and primates: A conflict of interest., pp. 40-59. In: Peterson, J.D. \& J. Wallis (eds.). Commensalism and Conflict: The Human-Primate Interface. Norman, Oklahoma: American Society of Primatologists, 483 pp.

Hill, C.M. \& A. Webber (2010). Perceptions of nonhuman primates 
in human-wildlife conflict scenarios. American Journal of Primatology 72(10): 919-924. https://doi.org/10.1002/ajp 20845

Houle, A. (1997). The role and phylogeography and behaviora competition in the evolution of coexistence among primates. Canadian Journal of Zoology 75: 827-846. https://doi.org/10.1139/ z97-106

Jayalath, P.P. \& A. Dangolla (2011). Capture and translocation of trouble making Toque Monkeys (Macaca sinica) in Mahakanda: Lessons learnt. In: Proceedings of the Annual Scientific sessions of the Sri Lanka Veterinary Association, Institute of Continuing Association, Education in Animal Production and Health, Gannoruwa, 35 pp.

Knox, R. (1681). An Historical Relation of the Island Ceylon in EastIndies. Richard Chefwell Publishers, London, $189 \mathrm{pp.}$

Marchal, V. \& C. Hill (2009). Primate crop-raiding: A study of loca perceptions in four villages in North Sumathra, Indonesia. Primates 24(1): 107-116. http://doi.org/10.1896/052.024.0109

Nahallage, C.A.D. \& M.A. Huffman, N. Kuruppu \& T. Weerasingha (2008). Diurnal primates in Sri Lanka and people's perception of them. Primate Conservation 23: 81-88. https://doi. org/10.1896/052.023.0109

Nahallage, C.A.D. \& M.A. Huffman (2013). Macaque - Human interactions in past and present day in Sri Lanka, pp. 135-148. In: Radhakrishna, A., M.A. Huffman \& A. Singha (eds.). Macaque Connections: Corporation and Conflict between Humans and Macaques. Springer Publication, London, $255 \mathrm{pp}$.

Nahallage, C.A.D., N. Kumarasinghe \& A. Dangolla (2018). Integrated management of Toque Macaque in affected areas of Kandy, Matale and Nuwaraeliya districts. A concept paper submitted to Statutory Board for Preservation of Kandyan Heritage, pp 1-5.
Nahallage, C.A.D. (2019). An ethnological perspective of Sri Lankan primates. Vidyodaya Current Research 1: 27-37.

Peiman K.S. \& B.W. Robinson (2010). Ecology and evolution of resource-related heterospecific aggression. The Quarterly Review of Biology 85: 133-158. https://doi.org/10.1086/652374

Perera, M. \& R. Vandercone (2016). Temporal patterns of crop raiding by diurnal primates in and around the Kaludiyapokuna Forest Reserve in the dry zone of Sri Lanka. In: Proceedings of the $5^{\text {th }}$ Asian Primate Symposium. University of Sri Jayewardenepura, Sri Lanka, $48 \mathrm{pp}$.

Prasad, T., S.J. Cabral, S.N. Weerakkody \& R. Rudran (2016). Human monkey conflict in Sri Lanka and mitigation efforts. In: Proceedings of the $5^{\text {th }}$ Asian Primate Symposium, University of Sri Jayewardenepura, Sri Lanka, 45pp.

Rudran, R. (1973). Adult male replacement in one-male troops of Purple-faced Langurs (Presbytis senex senex) and its effect on population structure. Folia Primatologica 19: 166-192.

Rudran, R. (2007). A survey of Sri Lanka's endangered and endemic Western Purple-faced Langur (Trachipithecus vetulus nestor). Primate Conservation 22: 139-144. https://doi.org/10.1896/052.022.0115

Rudran, R. \& S. Kotagama (2016). Strategy to conserve and coexist with Sri Lanka's monkeys. In: Proceedings of the $5^{\text {th }}$ Asian Primate Symposium, University of Sri Jayewardenepura, Sri Lanka, p. 17.

Shimizu, K. (2012). Birth control in female Japanese macaques at Iwatayama Monkey Park, Arashiyama, pp. 435-452. In: Leca, J., M.A. Huffman \& P. Vasey (eds.). The monkeys of Stromy mountain: 60 years of Primatological research on Japanese macaques of Arashiyama, Cambridge University Press, Cambridge, 517 pp.

Wilio ZOOREACH 
Dr. John Noyes, Natural History Museum, London, UK

Dr. Albert G. Orr, Griffith University, Nathan, Australia

Dr. Sameer Padhye, Katholieke Universiteit Leuven, Belgium

Dr. Nancy van der Poorten, Toronto, Canada

Dr. Kareen Schnabel, NIWA, Wellington, New Zealand

Dr. R.M. Sharma, (Retd.) Scientist, Zoological Survey of India, Pune, India

Dr. Manju Siliwal, WILD, Coimbatore, Tamil Nadu, India

Dr. G.P. Sinha, Botanical Survey of India, Allahabad, India

Dr. K.A. Subramanian, Zoological Survey of India, New Alipore, Kolkata, India

Dr. P.M. Sureshan, Zoological Survey of India, Kozhikode, Kerala, India

Dr. R. Varatharajan, Manipur University, Imphal, Manipur, India

Dr. Eduard Vives, Museu de Ciències Naturals de Barcelona, Terrassa, Spain

Dr. James Young, Hong Kong Lepidopterists' Society, Hong Kong

Dr. R. Sundararaj, Institute of Wood Science \& Technology, Bengaluru, India

Dr. M. Nithyanandan, Environmental Department, La Ala Al Kuwait Real Estate. Co. K.S.C.,

Kuwait

Dr. Himender Bharti, Punjabi University, Punjab, India

Mr. Purnendu Roy, London, UK

Dr. Saito Motoki, The Butterfly Society of Japan, Tokyo, Japan

Dr. Sanjay Sondhi, TITLI TRUST, Kalpavriksh, Dehradun, India

Dr. Nguyen Thi Phuong Lien, Vietnam Academy of Science and Technology, Hanoi, Vietnam

Dr. Nitin Kulkarni, Tropical Research Institute, Jabalpur, India

Dr. Robin Wen Jiang Ngiam, National Parks Board, Singapore

Dr. Lional Monod, Natural History Museum of Geneva, Genève, Switzerland.

Dr. Asheesh Shivam, Nehru Gram Bharti University, Allahabad, India

Dr. Rosana Moreira da Rocha, Universidade Federal do Paraná, Curitiba, Brasi

Dr. Kurt R. Arnold, North Dakota State University, Saxony, Germany

Dr. James M. Carpenter, American Museum of Natural History, New York, USA

Dr. David M. Claborn, Missouri State University, Springfield, USA

Dr. Kareen Schnabel, Marine Biologist, Wellington, New Zealand

Dr. Amazonas Chagas Júnior, Universidade Federal de Mato Grosso, Cuiabá, Brasil

Mr. Monsoon Jyoti Gogoi, Assam University, Silchar, Assam, India

Dr. Heo Chong Chin, Universiti Teknologi MARA (UiTM), Selangor, Malaysia

Dr. R.J. Shiel, University of Adelaide, SA 5005, Australia

Dr. Siddharth Kulkarni, The George Washington University, Washington, USA

Dr. Priyadarsanan Dharma Rajan, ATREE, Bengaluru, India

Dr. Phil Alderslade, CSIRO Marine And Atmospheric Research, Hobart, Australia

Dr. John E.N. Veron, Coral Reef Research, Townsville, Australia

Dr. Daniel Whitmore, State Museum of Natural History Stuttgart, Rosenstein, Germany.

Dr. Yu-Feng Hsu, National Taiwan Normal University, Taipei City, Taiwan

Dr. Keith V. Wolfe, Antioch, California, USA

Dr. Siddharth Kulkarni, The Hormiga Lab, The George Washington University, Washington,

D.C., USA

Dr. Tomas Ditrich, Faculty of Education, University of South Bohemia in Ceske

Budejovice, Czech Republic

Dr. Mihaly Foldvari, Natural History Museum, University of Oslo, Norway

Dr. V.P. Uniyal, Wildlife Institute of India, Dehradun, Uttarakhand 248001, India

Dr. John T.D. Caleb, Zoological Survey of India, Kolkata, West Bengal, India

Dr. Priyadarsanan Dharma Rajan, Ashoka Trust for Research in Ecology and the Environment

(ATREE), Royal Enclave, Bangalore, Karnataka, India

\section{Fishes}

Dr. Neelesh Dahanukar, IISER, Pune, Maharashtra, India

Dr. Topiltzin Contreras MacBeath, Universidad Autónoma del estado de Morelos, México

Dr. Heok Hee Ng, National University of Singapore, Science Drive, Singapore

Dr. Rajeev Raghavan, St. Albert's College, Kochi, Kerala, India

Dr. Robert D. Sluka, Chiltern Gateway Project, A Rocha UK, Southall, Middlesex, UK

Dr. E. Vivekanandan, Central Marine Fisheries Research Institute, Chennai, India

Dr. Davor Zanella, University of Zagreb, Zagreb, Croatia

Dr. A. Biju Kumar, University of Kerala, Thiruvananthapuram, Kerala, India

Dr. Akhilesh K.V., ICAR-Central Marine Fisheries Research Institute, Mumbai Research

Centre, Mumbai, Maharashtra, India

Dr. J.A. Johnson, Wildlife Institute of India, Dehradun, Uttarakhand, India

Amphibians

Dr. Sushil K. Dutta, Indian Institute of Science, Bengaluru, Karnataka, India

Dr. Annemarie Ohler, Muséum national d'Histoire naturelle, Paris, France

\section{Reptiles}

Dr. Gernot Vogel, Heidelberg, Germany

Dr. Raju Vyas, Vadodara, Gujarat, India

Dr. Pritpal S. Soorae, Environment Agency, Abu Dubai, UAE.

Prof. Dr. Wayne J. Fuller, Near East University, Mersin, Turkey

Prof. Chandrashekher U. Rivonker, Goa University, Taleigao Plateau, Goa. India

Dr. S.R. Ganesh, Chennai Snake Park, Chennai, Tamil Nadu, India

Dr. Himansu Sekhar Das, Terrestrial \& Marine Biodiversity, Abu Dhabi, UAE
Birds

Dr. Hem Sagar Baral, Charles Sturt University, NSW Australia

Dr. Chris Bowden, Royal Society for the Protection of Birds, Sandy, UK

Dr. Priya Davidar, Pondicherry University, Kalapet, Puducherry, India

Dr. J.W. Duckworth, IUCN SSC, Bath, UK

Dr. Rajah Jayapal, SACON, Coimbatore, Tamil Nadu, India

Dr. Rajiv S. Kalsi, M.L.N. College, Yamuna Nagar, Haryana, India

Dr. V. Santharam, Rishi Valley Education Centre, Chittoor Dt., Andhra Pradesh, India

Dr. S. Balachandran, Bombay Natural History Society, Mumbai, India

Mr. J. Praveen, Bengaluru, India

Dr. C. Srinivasulu, Osmania University, Hyderabad, India

Dr. K.S. Gopi Sundar, International Crane Foundation, Baraboo, USA

Dr. Gombobaatar Sundev, Professor of Ornithology, Ulaanbaatar, Mongolia

Prof. Reuven Yosef, International Birding \& Research Centre, Eilat, Israel

Dr. Taej Mundkur, Wetlands International, Wageningen, The Netherlands

Dr. Carol Inskipp, Bishop Auckland Co., Durham, UK

Dr. Tim Inskipp, Bishop Auckland Co, Durham, UK

Dr. V. Gokula, National College, Tiruchirappalli, Tamil Nadu, India

Dr. Arkady Lelej, Russian Academy of Sciences, Vladivostok, Russia

Dr. Simon Dowell, Science Director, Chester Zoo, UK

Dr. Mário Gabriel Santiago dos Santos, Universidade de Trás-os-Montes e Alto Douro,

Quinta de Prados, Vila Real, Portugal

Dr. Grant Connette, Smithsonian Institution, Royal, VA, USA

Dr. M. Zafar-ul Islam, Prince Saud Al Faisal Wildlife Research Center, Taif, Saudi Arabia

Mammals

Dr. Giovanni Amori, CNR - Institute of Ecosystem Studies, Rome, Italy

Dr. Anwaruddin Chowdhury, Guwahati, India

Dr. David Mallon, Zoological Society of London, UK

Dr. Shomita Mukherjee, SACON, Coimbatore, Tamil Nadu, India

Dr. Angie Appel, Wild Cat Network, Germany

Dr. P.O. Nameer, Kerala Agricultural University, Thrissur, Kerala, India

Dr. Ian Redmond, UNEP Convention on Migratory Species, Lansdown, UK

Dr. Heidi S. Riddle, Riddle's Elephant and Wildlife Sanctuary, Arkansas, USA

Dr. Karin Schwartz, George Mason University, Fairfax, Virginia.

Dr. Lala A.K. Singh, Bhubaneswar, Orissa, India

Dr. Mewa Singh, Mysore University, Mysore, India

Dr. Paul Racey, University of Exeter, Devon, UK

Dr. Honnavalli N. Kumara, SACON, Anaikatty P.O., Coimbatore, Tamil Nadu, India

Dr. Nishith Dharaiya, HNG University, Patan, Gujarat, India

Dr. Spartaco Gippoliti, Socio Onorario Società Italiana per la Storia della Fauna "Giuseppe

Altobello", Rome, Italy

Dr. Justus Joshua, Green Future Foundation, Tiruchirapalli, Tamil Nadu, India

Dr. H. Raghuram, The American College, Madurai, Tamil Nadu, India

Dr. Paul Bates, Harison Institute, Kent, UK

Dr. Jim Sanderson, Small Wild Cat Conservation Foundation, Hartford, USA

Dr. Dan Challender, University of Kent, Canterbury, UK

Dr. David Mallon, Manchester Metropolitan University, Derbyshire, UK

Dr. Brian L. Cypher, California State University-Stanislaus, Bakersfield, CA

Dr. S.S. Talmale, Zoological Survey of India, Pune, Maharashtra, India

Prof. Karan Bahadur Shah, Budhanilakantha Municipality, Kathmandu, Nepal

Dr. Susan Cheyne, Borneo Nature Foundation International, Palangkaraja, Indonesia

Dr. Hemanta Kafley, Wildlife Sciences, Tarleton State University, Texas, USA

\section{Other Disciplines}

Dr. Aniruddha Belsare, Columbia MO 65203, USA (Veterinary)

Dr. Mandar S. Paingankar, University of Pune, Pune, Maharashtra, India (Molecular)

Dr. Jack Tordoff, Critical Ecosystem Partnership Fund, Arlington, USA (Communities)

Dr. Ulrike Streicher, University of Oregon, Eugene, USA (Veterinary)

Dr. Hari Balasubramanian, EcoAdvisors, Nova Scotia, Canada (Communities)

Dr. Rayanna Hellem Santos Bezerra, Universidade Federal de Sergipe, São Cristóvão, Brazil

Dr. Jamie R. Wood, Landcare Research, Canterbury, New Zealand

Dr. Wendy Collinson-Jonker, Endangered Wildlife Trust, Gauteng, South Africa

Dr. Rajeshkumar G. Jani, Anand Agricultural University, Anand, Gujarat, India

Dr. O.N. Tiwari, Senior Scientist, ICAR-Indian Agricultural Research Institute (IARI), New

Delhi, India

Dr. L.D. Singla, Guru Angad Dev Veterinary and Animal Sciences University, Ludhiana, India

Dr. Rupika S. Rajakaruna, University of Peradeniya, Peradeniya, Sri Lanka

Dr. Bahar Baviskar, Wild-CER, Nagpur, Maharashtra 440013, India

Reviewers 2018-2020

Due to pausity of space, the list of reviewers for $2018-2020$ is available online.

The opinions expressed by the authors do not reflect the views of the Journal of Threatened Taxa, Wildlife Information Liaison Development Society, Zoo Outreach Organization, or any of the partners. The journal, the publisher, the host, and the partners are not responsible for the accuracy of the political boundaries shown in the maps by the authors.

Journal of Threatened Taxa is indexed/abstracted in Bibliography of Systematic Mycology, Biological Abstracts, BIOSIS Previews, CAB Abstracts, EBSCO, Google Scholar, Index Copernicus, Index Fungorum, JournalSeek, National Academy of Agricultural Sciences, NewJour, OCLC WorldCat, SCOPUS, Stanford University Libraries, Virtual Library of Biology, Zoological Records.

NAAS rating (India) 5.64
Print copies of the Journal are available at cost. Write to:

The Managing Editor, JoTT,

c/o Wildlife Information Liaison Development Society,

No. 12, Thiruvannamalai Nagar, Saravanampatti - Kalapatti Road,

Saravanampatti, Coimbatore, Tamil Nadu 641035, India

ravi@threatenedtaxa.org 


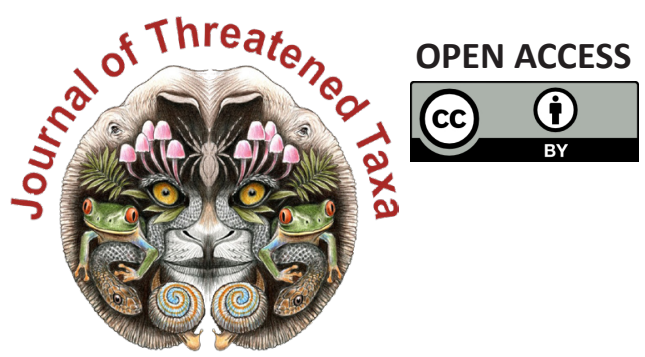

www.threatenedtaxa.org

The Journal of Threatened Taxa (JoTT) is dedicated to building evidence for conservation globally by publishing peer-reviewed articles online every month at a reasonably rapid rate at www.threatenedtaxa.org. All articles published in JoTT are registered under Creative Commons Attribution 4.0 International License unless otherwise mentioned. JoTT allows allows unrestricted use, reproduction, and distribution of articles in any medium by providing adequate credit to the author(s) and the source of publication.

\section{ISSN $0974-7907$ (Online) | ISSN $0974-7893$ (Print)}

\section{January 2022 | Vol. 14 | No. 1 | Pages: 20311-20538 \\ Date of Publication: 26 January 2022 (Online \& Print) DOI: 10.11609/jott.2022.14.1.20311-20538}

Articles

Estimating the completeness of orchid checklists and atlases: a case study from southern Italy

- Antonio Croce, Pp. 20311-20322

A floristic survey across three coniferous forests of Kashmir Himalaya, India - a checklist

- Ashaq Ahmad Dar, Akhtar Hussain Malik \& Narayanaswamy Parthasarathy, Pp. 20323-20345

Associations of butterflies across different forest types in Uttarakhand, western Himalaya, India: implications for conservation planning

- Arun Pratap Singh, Pp. 20346-20370

Comparison of bird diversity in protected and non-protected wetlands of western lowland of Nepal

- Jagan Nath Adhikari, Janak Raj Khatiwada, Dipendra Adhikari, Suman Sapkota, Bishnu Prasad Bhattarai, Deepak Rijal \& Lila Nath Sharma, Pp. 20371-20386

Local hunting practices and perceptions regarding the distribution and ecological role of the Large Flying Fox (Chiroptera: Pteropodidae: Pteropus vampyrus) in western Sarawak, Malaysian Borneo

- Jayasilan Mohd-Azlan, Joon Yee Yong, Nabila Norshuhadah Mohd Hazzrol, Philovenny Pengiran, Arianti Atong \& Sheema Abdul Aziz, Pp. 20387-20399

\section{Communications}

Macrolichens of Mathikettan Shola National Park, Western Ghats: a preliminary investigation with some new records

- Aswathi Anilkumar, Stephen Sequeira, Arun Christy \& S.M. Arsha, Pp. 20400-20405

New distribution record of globally threatened Ocean Turf Grass Halophila beccarii Ascherson, 1871 from the North Andaman Islands highlights the importance of seagrass exploratory surveys

- Swapnali Gole, Prasad Gaidhani, Srabani Bose, Anant Pande, Jeyaraj Antony Johnson \& Kuppusamy Sivakumar, Pp. 20406-20412

An inventory of new orchid (Orchidaceae) records from Kozhikode, Kerala, India - M. Sulaiman, C. Murugan \& M.U. Sharief, Pp. 20413-20425

Abundance and spatial distribution analyses of Stemonoporus moonii Thwaites (Dipterocarpaceae) - a critically endangered species endemic to Sri Lanka - K.A.M.R.P. Atapattu, H.D.D.C.K. Perera, H.S. Kathriarachchi \& A.R. Gunawardena, Pp. 20426-20432

Plant diversity of Point Calimere Wildlife Sanctuary and fodder species grazed by the Blackbuck Antilope cervicapra L.

- Ashutosh Kumar Upadhyay, A. Andrew Emmanuel, Ansa Sarah Varghese \&

D. Narasimhan, Pp. 20433-20443

Raptors observed (1983-2016) in National Chambal Gharial Sanctuary: semi-arid biogeographic region suggestions for parametric studies on ecological continuity in Khathiar-Gir Ecoregion, India

- L.A.K. Singh, R.K. Sharma \& Udayan Rao Pawar, Pp. 20444-20460

Nesting success of Sharpe's Longclaw (Macronyx sharpei Jackson, 1904) around the grasslands of lake Ol'bolossat Nyandarua, Kenya

- Hamisi Ann Risper, Charles M. Warui \& Peter Njoroge, Pp. 20461-20468

Population, distribution and diet composition of Smooth-coated Otter Lutrogale perspicillata Geoffroy, 1826 in Hosur and Dharmapuri Forest Divisions, India - Nagarajan Baskaran, Raman Sivaraj Sundarraj \& Raveendranathanpillai Sanil, Pp. 20469-20477

Utilization of home garden crops by primates and current status of human-primate interface at Galigamuwa Divisional Secretariat Division in Kegalle District, Sri Lanka

- Charmalie Anuradhie Dona Nahallage, Dahanakge Ayesha Madushani Dasanayake, Dilan Thisaru Hewamanna \& Dissanayakalage Tharaka Harshani Ananda, Pp. 2047820487
Revival of Eastern Swamp Deer Rucervus duvaucelii ranjitsinhi (Groves, 1982) in Manas National Park of Assam, India

- Nazrul Islam, Aftab Ahmed, Rathin Barman, Sanatan Deka, Bhaskar Choudhury, Prasanta Kumar Saikia \& Jyotishman Deka, Pp. 20488-20493

Trypanosoma evansi infection in a captive Indian Wolf Canis lupus pallipes - molecular diagnosis and therapy

- Manojita Dash, Sarat Kumar Sahu, Santosh Kumar Gupta, Niranjana Sahoo \& Debarat Mohapatra, Pp. 20494-20499

View Point

COVID-19 and civil unrest undoing steady gains in karst conservation and herpetological research in Myanmar, and an impediment to progress - Evan S.H. Quah, Lee L. Grismer, Perry L. Wood, Jr., Aung Lin \& Myint Kyaw Thura, Pp. 20500-20502

\section{Short Communications}

Morphological characterization and mt DNA barcode of a tiger moth species, Asota ficus (Fabricius, 1775) (Lepidoptera: Noctuoidea: Erebidae: Aganainae) from India - Aparna Sureshchandra Kalawate, K.P. Dinesh \& A. Shabnam, Pp. 20503-20510

Distribution of Smooth-coated Otters Lutrogale perspicillata (Mammalia: Carnivora: Mustelidae): in Ratnagiri, Maharashtra, India

- Swanand Patil \& Kranti Yardi, Pp. 20511-20516

Wildlife at the crossroads: wild animal road kills due to vehicular collision on a mountainous highway in northwestern Himalayan region

- Muzaffar A. Kichloo, Asha Sohil \& Neeraj Sharma, Pp. 20517-20522

Notes

Robiquetia gracilis (Lindl.) Garay-a new record to the flora of Anamalai Hills, Tami Nadu, India

- B. Subbaiyan, V. Ganesan, P.R. Nimal Kumar \& S. Thangaraj Panneerselvam, Pp. 20523-20525

Ipomoea laxiflora H.J. Chowdhery \& Debta (Convolvulaceae): new records for the Western Ghats and semiarid regions

- Sachin M. Patil, Ajit M. Vasava, Vinay M. Raole \& Kishore S. Rajput, Pp. 20526-20529

Counting the cost: high demand puts Bunium persicum (Boiss.) B.Fedtsch. in jeopardy

- Monika Sharma, Manisha Mathela, Rupali Sharma, Himanshu Bargali, Gurinderjit S Goraya \& Amit Kumar, Pp. 20530-20533

First record of Parasitic Jaeger Stercorarius parasiticus (Aves: Charadriiformes: Stercorariidae) from inland freshwater Inle Lake, Myanmar

- Sai Sein Lin Oo, Myint Kyaw, L.C.K. Yun, Min Zaw Tun, Yar Zar Lay Naung, Soe Naing Aye \& Swen C. Renner, Pp. 20534-20536

\section{Book Review}

Capparis of India

- V. Sampath Kumar, Pp. 20537-20538
Publisher \& Host
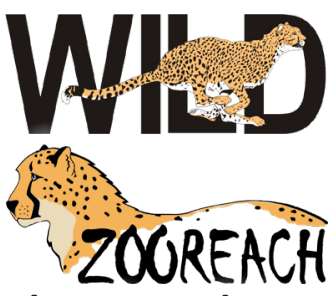

Threatened Taxa 